\title{
Eukaryotic Translation Initiation Factor 3 Subunit B
}

National Cancer Institute

\section{Source}

National Cancer Institute. Eukaryotic Translation Initiation Factor 3 Subunit B. NCI

Thesaurus. Code C96376.

Eukaryotic translation initiation factor 3 subunit B $(814 \mathrm{aa}, \sim 92 \mathrm{kDa})$ is encoded by the human EIF3B gene. This protein plays a role in translation initiation. 